\section{Ultrasonically guided fine needle aspiration of suspect parathyroid tissue to determine parathyroid hormone concentration}

Since the study of Arima et al, ${ }^{1}$ several reports have confirmed that enlarged parathyroid glands can be located preoperatively using ultrasound. ${ }^{2}$ A general problem has been the difficulty of distinguishing nodular thyroid lesions from enlarged parathyroid glands. ${ }^{2} 3 \mathrm{We}$ report two cases in which parathyroid adenoma was correctly diagnosed using ultrasonically guided fine needle aspiration for determination of parathyroid hormone concentration.

\section{Case reports}

CASE 1

A 39 year old woman presented with hypercalcaemia. Two years previously she had had a stone removed from her left kidney, and she had recently had a one day episode of severe haematuria.

On admission serum calcium concentration was $3.66 \mathrm{mmol} / 1(14.7 \mathrm{mg} /$ $100 \mathrm{ml}$ ) (normal 2.20-2.70 mmol/1 (8.8-10.8 mg/100 ml)); ionised calcium $1.80 \mathrm{mmol} / 1(7.2 \mathrm{mg} / 100 \mathrm{ml})$ (normal 1.13-1.24 mmol/1 (4.5-5.0 mg/100 ml)); phosphate $0.49 \mathrm{mmol} / 1(1.5 \mathrm{mg} / 100 \mathrm{ml}$ ) (normal 0.80-1.50 mmol/1 (2.5$4.6 \mathrm{mg} / 100 \mathrm{ml})$ ); and parathyroid hormone $4.4 \mu \mathrm{g} / \mathrm{l}$ (normal 0.22-0.50 $\mu \mathrm{g} / \mathrm{l}$ ). Serum creatinine concentration was normal. Intravenous pyelography showed four stones in the right kidney. Parathyroid subtraction scintigraphy of the neck was inconclusive, but ultrasonography showed a $4 \times 1.5 \times 1.5 \mathrm{~cm}$ nodule with a low intensity echogenic pattern posterior to the lower pole of the right lobe of the thyroid gland. Fine needle (22 gauge) aspiration of the abnormal area (parathyroid tissue) and the thyroid gland was performed under ultrasonic guidance after injection of $1 \mathrm{ml}$ isotonic saline. The aspirated specimens $(0.1 \mathrm{ml}$ each) were diluted to a final volume of $1 \mathrm{ml}$ with sterile water and centrifuged, ard finally the supernatant was analysed by $C$ terminal radioimmunoassay. ${ }^{4}$ Parathyroid hormone concentrations were $150 \mu \mathrm{g} / \mathrm{l}$ in the parathyroid tissue and $2.0 \mu \mathrm{g} / 1$ in the thyroid gland.

At operation the ultrasonic finding was confirmed and a parathyroid adenoma removed. Postoperatively, serum calcium concentration returned to normal.

CASE 2

A 69 year old woman presented with hypercalcaemia and intermittent sinoatrial block. She had had dyspnoea and chest pains on effort for two years.

On admission serum calcium concentration was $3.08 \mathrm{mmol} / 1(12.3 \mathrm{mg} /$ $100 \mathrm{ml}$ ); ionised calcium $1.61 \mathrm{mmol} / 1(6.5 \mathrm{mg} / 100 \mathrm{ml})$; phosphate $0.71 \mathrm{mmol} / 1$ $(2.2 \mathrm{mg} / 100 \mathrm{ml})$; and parathyroid hormone $1.14 \mu \mathrm{g} / \mathrm{l}$. Pyelography and radiography of the chest and skeleton yielded normal results. Echocardiography showed stenosis of the aortic valves: Ultrasonography showed a $1 \times 1 \times 4 \mathrm{~cm}$, well defined nodule with a homogenous low intensity internal echo pattern inferior to the upper pole of the thyroid gland. Aspiration of the abnormal area (parathyroid tissue) and the thyroid gland was performed under ultrasonic guidance as in case 1; parathyroid hormone concentrations were 200 and $1.5 \mu \mathrm{g} / \mathrm{l}$, respectively. A parathyroid adenoma was removed, and serum calcium concentration returned to normal postoperatively.

\section{Comment}

Distinguishing enlarged parathyroid glands from nodular thyroid lesions is difficult because on ultrasonography both lesions may show the same pattern of echoes, resulting in false positive findings. ${ }^{2}$ Fine needle aspiration from masses suspected of being parathyroid glands was described by Doppman et al, who used computed tomography and a mid-region specific radioimmunoassay to determine parathyroid hormone concentrations. ${ }^{5}$ Using a commercially available radioimmunoassay we found a small concentration of parathyroid hormone in the thyroid specimens from our patients, but in both cases the concentrations were different from those in the parathyroid tissue. The difference in concentration between thyroid and parathyroid glands depends on the volume aspirated and dilutional factors. We eliminated these problems by standardising the procedure for aspiration of the two glands.

Ultrasonically guided aspiration of suspect parathyroid tissue may improve the possibility of locating abnormal parathyroid tissue preoperatively. The value of preoperative ultrasonography in patients with clinical and biochemical evidence of primary hyperparathyroidism depends on the surgical approach used. It may also be helpful for patients requiring re-exploration, those with ectopic or intrathyroidal $\underline{\underline{T}}$ parathyroid tissue, and those requiring a shortened surgical procedure as in case 2 .

1 Arima M, Yokio H, Sonoda T. Preoperative identification of tumor of the parahyroid by ultrasonotomography. Surg Gynecol Obstet 1975;141:242-4. reasons for unsatisfactory ultrasonographical localization of parathyroid glands. Eur $\mathcal{Y}$ Radiol (in press). ough BH, Reeve TS, Duffy PJ, to ultrasound scanning prior to surgery in patients with hyperparathyroidism. World f Surg $1981 ; 5: 91-5$.

等 Invest $1974 ; 54: 1382-94$

Doppman JL, Adrian GK, Stephen JM, et al. Aspiration of enlarged parathyroid glands for parathyroid hormone assay. Radiology 1983;148:31-5.

(Accepted 1 November 1984)

Department of Internal Medicine and Endocrinology, Herlev

University Hospital, DK 2730 Herlev, Denmark

STEEN KARSTRUP, MD, registrar

LASZLO HEGEDU'S, MD, clinical assistant

Ultrasonic Laboratory, Herlev University Hospital

SØREN TORP-PEDERSEN, MD, clinical assistant

HANS HENRIK HOLM, MD, head of department

Correspondence to: Dr Laszlo Hegedüs.

\section{Long term treatment of acromegaly with a long acting analogue of somatostatin}

Somatostatin is a potent inhibitor of secretion of growth hormone in patients with acromegaly. ${ }^{1}$ The native tetradecapeptide has a half life of less than four minutes, but a long acting analogue (selective mini somatostatin, SMS 201-995, Sandoz) has been shown to be $20 \%$ times more potent in inhibiting secretion of growth hormone in animals. ${ }^{2}$ Selective mini somatostatin is an octapeptide protected against degradation by a D-phenylalanyl residue at the $N$ terminus and an amino alcohol at the $C$ terminus. We report initial results of using this analogue in patients with acromegaly.

\section{Patients, methods, and results}

Eight patients (six men, two women) gave their informed consent for the trial. Four had not received any previous treatment (cases 5, 6, 7, and 8), three had received only interstitial irradiation (cases 1,2 , and 4), and one (case 3) had received both interstitial and external irradiation and been treated with bromocriptine until two weeks before our study. Sweating was prominent in seven patients, and one (case 3 ) had severe headache.

Both before and during treatment with selective mini somatostatin growth hormone, insulin, and blood glucose concentrations were monitored at regular intervals for 24 hours in each patient. All subjects received selective mini somatostatin subcutaneously for three days. Three patients were given a $50 \mu \mathrm{g}$ dose and two patients a $100 \mu \mathrm{g}$ dose twice daily (at 0800 and 2000). The three remaining patients were treated thrice daily with $100 \mu \mathrm{g}$ at 0800 ,

Mean (SEM) circulating concentrations of growth hormone before and after three days' treatment with selective mini somatostatin, and reductions in concentration after treatment

\begin{tabular}{|c|c|c|c|c|c|}
\hline \multirow[b]{2}{*}{ Case No } & \multirow[b]{2}{*}{$\begin{array}{c}\text { Age } \\
\text { (years) }\end{array}$} & \multicolumn{2}{|c|}{ Mean concentration (mIU/l) } & \multicolumn{2}{|c|}{$\%$ reduction after treatment } \\
\hline & & $\begin{array}{c}\text { Before } \\
\text { treatment }\end{array}$ & $\begin{array}{c}\text { After } \\
\text { treatment }\end{array}$ & $\begin{array}{l}\text { Mean over } \\
24 \mathrm{~h}\end{array}$ & $\begin{array}{c}2-4 h \\
\text { after dosing }\end{array}$ \\
\hline \multicolumn{6}{|c|}{$50 \mu g$ twice daily } \\
\hline $\begin{array}{l}1 \\
2 \\
3\end{array}$ & $\begin{array}{l}53 \\
44 \\
28\end{array}$ & $\begin{array}{l}32.5(0.4) \\
29 \cdot 2(0.6) \\
42.0(1.1)\end{array}$ & $\begin{array}{r}11.4(2.0) \\
6.4(0.7) \\
22.5(2 \cdot 1)\end{array}$ & $\begin{array}{l}64 \\
78 \\
46\end{array}$ & $\begin{array}{l}81 \\
92 \\
78\end{array}$ \\
\hline \multicolumn{6}{|c|}{$100 \mu g$ twice daily } \\
\hline $\begin{array}{l}4 \\
5\end{array}$ & $\begin{array}{l}30 \\
55\end{array}$ & $\begin{array}{l}27 \cdot 3(1 \cdot 3) \\
48 \cdot 1(2 \cdot 8)\end{array}$ & $\begin{array}{r}5.9(0.4) \\
11.5(0.8)\end{array}$ & $\begin{array}{l}79 \\
76\end{array}$ & $\begin{array}{l}95 \\
93\end{array}$ \\
\hline \multicolumn{6}{|c|}{$100 \mu \mathrm{g}$ thrice daily } \\
\hline $\begin{array}{l}6 \\
7 \\
8\end{array}$ & $\begin{array}{l}57 \\
26 \\
23\end{array}$ & $\begin{array}{r}50.4(1.4) \\
90.8(2.0) \\
234.0(1.9)\end{array}$ & $\begin{array}{r}16.4(0.8) \\
60.7(2.0) \\
133.0(9.0)\end{array}$ & $\begin{array}{l}68 \\
30 \\
43\end{array}$ & $\begin{array}{l}83 \\
50 \\
95\end{array}$ \\
\hline
\end{tabular}

